\title{
The Structure of Indonesian Fiction before and after Period of Reform in Indonesia
}

\author{
M. Ismail Nst, Bakhtaruddin Nst., and Zulfadhli \\ Visual Art Department, FBS \\ State University of Padang \\ yofita.sandra@yahoo.com
}

\begin{abstract}
Paper is discuss about literature development in Indonesia specific prose structure from early period 1990 to 2016. Period divided is two part, that is: before the reformasi period, termed the orde baru period (1990-1997) and after the reformasi period (1998-2016). Wellek and Warren (1995) states that there is no significan between politic change with literature change on something country. However, can not denied that change all that happen on human life including from political developments.That matter be important themes discussed by authors in his works. Research purposes is earn development literature work structure before reform and after reform. Data Analysis done by induction-description. Data interpreted by theory combination. Research result got that structure literature work has its own characteristics if analogy with previous period. The development is visible from various elements formes intrinsic and extrinsic. The elements concerned theme, figures character, setting, and language style. Then, the values that the mission of the author (extrinsic elements) be delivered more straightforward, impressed what it is. Something that is considered taboo before on period no longer taboo because function describe the nature of human exsistence. Then, the other developments is appeared literature work with religious colours with the overseas setting and the arabic.
\end{abstract}

Keywords-Prose fiction, Orde Baru and Reformasi in Indonesia, Fictional Structure

\section{INTRODUCTION}

Research the literary structure of each period in the study of literary history is an important step to formulate the development of a countrys literature. The research aim for investigation unification various elements that establish structure that connected singly until each element substansial sustain another elements. Researh result will describe totality of meaning from unification each structure elements. Besides that, more signify is development of literature each period will visible clearly.

Whatever meaning assessment literature without structure research must begins from structure literature. Meaning wholeness can be obtained when reader elucidate that of elements and each function in structure. Meaning will more whole again if sustained with variety paradigm for increase analysis and problem that will discuss.

In Indonesia, discussion the literature works structure from 1920 until 1990 has been done by some literary scientists, among others: HB. Jassin, Ajip Rosidi, Hasanuddin WS., Maman S. Mahayana, dan Rachmat Djoko Pradopo. Pradopo in his book that title Beberapa Teori Sastra, Metode Kritik dan Penerapannya discuss about progress of elements esthetic and extraesthetic the elements literature works during that period. Then, Korrie Layun Rampan wrote the latest generation of Indonesian literature which she named with Angkatan 2000. The book this is one of wich discuss the new development the literature works. After year 1990, research progress at the literature works structure wich integrated not much. Research only do by scholar Indonesian literature from various university at Indonesia wich research choose modern literature when finish its study. This research important do ing to result description characteristic work each period between 10 until 20 years. The characteristic contain formulate uniqueness one literature work group at time and one literature work group at period another.

\section{Literature Review}

a. Structure and Structuralism

Basic concepts of structure in literary theory based at language structure viewpoint like is wich declared by Ferdinand de Saussure (1857-1913). The elements signifie and signifian be the beginning formulate the elements structure literature work. Luxemburg (1989:36) declared that signifie or wich give meaning become aspect of form in sign or symbol while signifian is wich is interpreted. Relationship between both occur arbitralily and according to agreement owner of the language.

Structuralism in literature then developing in the Ceko wich initiated by Roman Jakobson, Jan Mukarovsky, and Felix Vodicka. This is of genre evolve concepts that literature work structure there are two aspect; literature work as artefac and as esthetic object.

According to Barry (2002:34) structuralism emphasize that of meaning of context must be in the parts structure wich large. That matter be supported by perception of world view and experience sequence. Therefore, meaning constitute attribute from a 
sign. Approach structure literature work must based from invidual interpretation and combination wich accompany it towards understanding wich wider from the parts wich shape it. How it works is viewing parts is whole.

b. The Elements of Structure from Poetry, Prose, and Drama

According to Robert Stanton (2007:9-11) authors merge fact and theme then be supported by literary means as conflict, point of view, symbolism, irony, etc. All it integrated established a building and it adhesive is language. All that means have each function wich can structure forming as whole.

Then, Stanton classify the all element a fiction structure on two kinds, that is: narrative facts and Narrative means. Narrative of facts includes: plot, character, setting, and theme. That matter be main component in each fiction prose. Means of Narrative consist from: title, point of view, language style, various of symbol, and irony. The that elements be proponent wich sterengthen of narrative facts. Although the supporter of elements, it is can not be removed just like that because has an important role establish a structure..

The elements formers poem different wich a prose. According Alterbend (Pradopo,1990:13) poem aesthetic can seized wich various of way, example use of visual form: typography and stanza composition. Then, use of sounding of poem wich of comprise rhyme, asonansi, alliteration, figurative sounding, symbol of taste, and orchestration. Besides that, the aesthetic of poetry could also do wich of way the utilization of diction, figurative language, means of rethoric, use of punctuation, language style, etc.

\section{METHOD}

The research this is qualitative kind because data wich processed not data wich related with a calculation with formula. Then, data not tested in the lab. The data of research interpreted with way of referring in to theory. The data analysis doing wich inductive-description. The research population is all of literature works wich publish at early from year 1990 up to 2016 . Based on observation from reference of various: library, the books of literary history, and the critical of literary, internet, and bookstore, the literature works of wich will the discussed as much of 32 novels. That amount divided on te two of period: first, the novels wich of published before reformasi period as much 4 novels. Second, the novels wich of published after period reformasi as much 28 novels. The criteria determened of sampel besides based on published of year also based on complexion the elements of structure wich contained in to works has.

Analysis data doing wich several ways, i.e.: the data wich there is in the format data collection interpreted one by one corresponding wich of group its. After obtained the data description wich strengthened wich interpretation and then the that structure of fiction between a period of orde baru with of period reform compared.

\section{FINDING AND DISCUSSION}

1. The Characterization

The character of actors at Indonesian novels wich published before of reformasi corresponding with condition wich happen politically on the time its. The time span 1990 up to 1998 is period of orde baru regime wich more binding the author in for expression if compared after the power of orde baru the ends. The expression of freedom overshadowed by the system of power.

The change of political and the life community of Indonesian after tragedy 1965 is transition regime orde baru to the reformasi era. Orde baru building of community economy after disorganized because NKRI not yet organized of well effect from commotion te political elits at the time its. The tyranny of orde baru with aim ruling in lifetime evidently synergize with appearance of practic corruption, collution, and nepotism in torso the government system. As a result, burdened of countries with the lot of debt. Marginalisasi begin spread because centralistic of elitism. Person wich want survive that circle must have competence for made Asal Bapak Senang (ABS). The that inequality cause growth social antipathy and eventually, all of the ends after tragedy 1998.

Implementation of the authors' freedom of expression one of them is the theme of the talked about is not as free as the novels published after period of reformasi. Therefore, the actors character's is also a manifestation of the issues discussed in the work. If there are literary works that protest the power of the orde baru regime, then it works popular after the weakening or end of the regime.

One of the novels published before the reformasi as wich of made up by Nh. Dini wich titled Tirai Menurun. The character of the actors in the novel is someone a respectful and obedient to the parents. The way of life is based on Javanese culture.

The character of actors of a free is found in the novel of Jazz, parfum, dan Insiden by Seno Gumira Ajidarma. In this novel, the rulers actually get a defense because the shooting incident of the demonstrators was completely not soldiers mistake. The defense of this ruler may be one of the authors' strategies in order for his work to be accepted for publication. On the other hand in the novel same, the next major character from the actor another is a free-living woman. Has a role a play girl and lesbian with alternating of couple.

Another character who is free and dare to criticize the orde baru of regime found at Ayu Utami's novel of title Saman. The Actors of Saman is an activist sought by the orde baru of regime. Saman finally fled to Prabumulih. He is a priest. However, in the same place he was accused of sparking a conflict for provoking citizens against the will of the government to turn rubber 
plantations into oil palm plantations. Finally, Saman escape abroad. The novel of story this continued later on Larung novel published three years later.

The representation of the character more straightforward and courageous character but hidden through the use of mystic in the the story of archipelago is found in the novel Arok Dedes written by Pramudya Ananta Toer. Ken Arok's character is firm, cunning, and soulless leader. Arok attempted a coup against the Ametung administration. Arok managed to achieve that desire. He was able to transform himself from the descendants of sudra to the descendants of the nobility. Arok undertook a non-war resistance way to depose Ametung.

\section{Setting}

The use of setting found in novels published before the reformasi other than the place and the background of a general nature, there are also some setting areas in Indonesia such as Jakarta, Medan, Prabumulih, Salatiga, Madiun, and Kediri. Then, the setting of time of the year 1960, November 1996, Around 1142 saka year (1220 AD). The use of setting of social was found among others the life of the villagers in Java, the conflict between people, the November 1996 of incident, and rebellion of the comunity on the time of kingdom.

\section{The Language Style}

The style of language found in novels before reformasi era is not much influenced by foreign languages. English is used only to name objects or specific terms. The rest, the language used by the author is the javanis language. The aesthetic nuances of literary are more visible at the novels before the reformasi era. That it is relevant to the situation at that time so that values wich of the author's mission is concealed with the use of symbolic styles, setting of events and symbolizations. The most widely used types of figurative languages are personification, metaphor, hyperbole, irony, sarcasm, euphemism, litotes, eponymous, repetition, and antonomasia.

\section{Theme}

The themes found are also diverse. These themes include: the hope confronted by the social strata told trough in play of wayang, the habit of the villagers who always want to leave their village to move and life in the city, the colorsfull of life and how humans life and enjoy it, the life story a prostitutes, ideologies never die, and a cunning coup to seize leadership without war.

\section{Extrinsic Elements of Literary Works}

Aspects of value include the relationship of man to himself, man with other human beings, man with God, and man with nature. It became the mission of the author he implicit in novel events. Everything is discussed in some aspects related to the life of the actors and the use of the setting.

\section{The Indonesia Fictional Structure (Period 1999 s.d. 2016)}

The dynamics of Indonesian society, especially on the social, cultural, political, religious, and individual of humanity are the themes the author always be appointed in his work. The issues raised are the hegemony of elitism that spans the gap between the lower and upper classes thus building a new colonialism in the life of society. Literary works became one of the container that voiced those gaps and became an art document in the current dynamics of human life.

The transition of the orde baru into the reformasi era building a new paradigm in various aspects mainly decided the node of doctrinization of the orde baru regime. Political parties spring up like mushrooms. Euphoria of society in expressing opinions like someone who just breathed free air. The structure of state administration is more open. The involvement of TNI-POLRI in the constitutional body is regulated and restricted by law. Primordiality begins to fade as the pluralistic principle begins to be implemented. He is not just in located the garuda grip (symbol/emblem of Indonesian state). The culture of each society wich there is in Indonesian began to grow in accordance with the principles of Pancasila.

The change also affected the growth of literary works in Indonesia. Freedom of expression in the works is no longer limited by political policy. The works that had been assumed to be smelling of resistance to tyranny, which was forbidden to the trading, can now be read and found in bookstores. The changes that is can also be seen from aspects of the structure of the works both in terms of intrinsic and extrinsic. The change is contained in the aspect of the actors or the characterization, setting, language style, theme, and of content the values in the works.

\section{The Actors and The Characterizations}

The character of the novel published after the reformasi of era describes the human attitude as it is. The character on general is dynamic (arround character), changing like an ever-changing human being. The character of actors becomes one of the means for the author in expressing the values that become his mission. The actors are not made from as author dolls. The Change of the character of actors exactly according to the situation of events described in the novel.

The character of the main character in novel with title Orang-Orang Proyek published in 2004, for example, reflects people who want to live honestly. The main character named Kabul works in a company with many projects. The projects he does are 
always honest. When his honesty is at stake because his boss tells him to the do it corruption the project funds, he is willing to withdraw from the job. Kabul has a resolute character of the establishment. On the other hand, the character of Baldun is inversely proportional to Kabul. Baldun's figure is portrayed as a sneaky person. He is concerned about the construction of the mosque but in a way that is not good because the donation funds were taken from the project funds. The names of actor in the post-reform novel is also varied There is a naming in accordance with the name the regional of eachs and there is also the name of the influence of Western culture, Arab traditions, and Indian traditions.

\section{Setting}

Another aspect that develops in novels published after the reformasi era is the use of the setting wich various. There is three setting are found that is place, time, and social setting. Setting of the place there are two types, namely: in Indonesia and outside Indonesia. Setting wich located Indonesia beside the place, like: Bali, Lombok, Makasar, Toraja, Papua, Manokwari, Wamena, up to you Baliem Valley. In addition, the found setting also there are is beyond Indonesia such as New Jersey, Frankurt, San Fransisco, Quebec, Japan, Moscow, Canada, and Germany. Beside the use setting place and time, also the found a setting with background social, for example: the social situation of Bali society with Hindu society, Minangkabau society in Padang city, rural atmosphere in West Java especially Bantaran Cibawong, Society with western and Egyptian culture, rural community in Papua, the life society of Batak, and life of Lombok people.

\section{The Language Style}

The language style elements are also found to be diverse. In addition to the pronunciation style in Indonesian. Then, pronunciation of style using a foreign language, among anothers: English, Arabic, French, and Russian. The tendency of foreign language usage is found in English and Arabic. Therefore, the Indonesian novel after the reformasi of era developed with the style of English pronunciation and the arabic. In addition, the found also many use of figurative language. The widely used figuratively languages are personification, metaphor, hyperbole, simile, euphemism, repetition, and irony.

\section{Theme}

The theme carried is also diverse expanded wich to the outside of Indonesia and local color. He discusses the life of Indonesian society in the era of globalization. Indonesians living in other countries.

\section{Extrinsic Elements of Literary Works}

The values contained in Indonesian novels are also developed in accordance with the author's environment. The environment becomes the first source and model when it builds its imaginative creativity process. Types or categories of values include religion, education, politics, the natural environment, and science and technology. The scope of the theme includes the relationship of man with himself, between mankind, and God.

\section{Comparison of Indonesian Fictional Structure Before and After Reformasi}

In addition to the theme of deity, another theme found is about human relationships with nature, as follows: 1). A lot of knowledge and has not been revealed. We are required to open our eyes and preserve the nature. 2). We must be sensitive to the signs of nature. Nature is not only to be enjoyed, but also to be read and maintained.

The characterization figures in both periods tend to be dynamic (around character). The figures of fixed or flat character are not widely found. The actors puppet the author. However, the difference of characters novels at reformasi era is aspect religious from the actors not so highlighted. The different with character of figures in the novels after reformasi. The tendency always comes down to religious attitudes. Religiusity is spread, not only Islam but also other religions recognized in Indonesia. The actors of character in the novels before the reformasi is show that the actors are still thick with the culture of Indonesia. Aspect multicultural the actors developed but limited to territorial Indonesia whereas the characters of actors after reformasi aspect multicultural a developing to be across countries. Therefore, the character of before reformasi is still nuanced Indonesian, still indo as yourself, while the actors in novels after reformasi is transitional. The Indonesian identity began to blur because it was suspended by the nature of western culture and the arab. The character is called by Hunter (in Foulcher and Day, 2008: 135) indo as self others.

Language style in novels published before the reformasi is still strong affected aff with the use of Indonesian and local languages. The benefits of local language use is reinforce the aesthetic value of the work by means of more cultural. The style of the novels published after the reformasi in general are English and Arabic. This results in a blurring of the boundary between fiction novels and popular novels.

Then, the themes contained in pre-reformasi novels are still issues of human relationships between the opposite sex and social criticism problems. If there is criticism for the ruler, it is hidden symbolically so that for ordinary readers it is difficult to connect the issue with the author's mission in to works. The phenomenon, for example, appears at the novel Arok Dedes wich wrote by Pramudya Ananta Toer. The novel it is made when its author is imprisoned criticizes the way of the rise and rule of a new power over the old power. Arok committed a coup d'etat to Tunggul Ametung as a ruler in an ingenious way. He seems to be 
outside the action so that on Arok is considered a hero. Uniquely, Pram's works began to appear in the market after the reformasi era occurred. Previously, he only became an artifact that is stored on the author or the surrounding environment because it is suspected of containing communist elements. So also in the novel Jazz, Parfum, dan Insiden wich wrote by Seno Gumira Ajidarma. On the cover of the novel, word the insiden (incident) was affixed with a red background. That ir, the symbol indicates that the subject matter is emphasized on that aspect. However, the theme of the November incident is obscured with the theme of the glamorous world of by lesbian night women. This phenomenon is also found in Ayu Utami's Saman novel. The novel tells of Saman, the activist, who was hunted for fighting the government. He finally saved himself to abroad. The story of Saman is obscured by the presence of Sihar, Laila, Yasmin, chocolate, etc. in a series of stories.

The themes of novels published after reformasi discussed the humanitarian issues wrapped by religiosity, educational, sporting, multicultural, and globalization issues. Transnational crimes not found in pre-reformasi novels are in novels published in after reformasi. Furthermore, the topic is not only about the problems of human being domiciled in Java and Sumatera but also extends to various parts of Eastern part of Indonesia such as Bali, Makasar, Lombok, Toraja, and Papua. Likewise with cultural issues, not only the cultural conflicts of Java, Sundanese, and Minangkabau but also the culture of Bali, Toraja culture, Lombok Culture, Chinese Culture, and Papuan culture. Many new and young authors of popping up come up with their owns characteristics, among others: Eka Kurniawan, Andrea Hirata, Habiburrahman El Shirazy, Lelila S. Chudori, Dee Lestari, Dorothea Rosa Herliany, Oka Rusmini, and others. Interestingly, in this period, the old writer was able to position himself as a writer who also had his own character by maintaining nationalism as did by Sapardi Djoko Damono with his two new novels Hujan Bulan Juni and Trilogi Soekram and Remy Silado with some of his new works, among others, Perempuan Bernama Arjuna 4. Some other authors famous like Seno Gumira Ajidarma, Ayu Utami, Djenar Maesa Ayu, and others also of accompany the progress of Indonesian literature.

Therefore, the period from 2000 to 2016 Indonesian literature progressed quantitatively with the number of new literary works emerging from new the authors as well. Then, the storytelling dimensions not only regionally but also part of the theme of life of global society.

\section{CONCLUSION AND RECOMMENDATION}

Based on the result of the research, it can be concluded that Indonesian literature especially the prose fiction genre which was published before the reformasi and after the reformasi at the period of 1990 until 2016 has developed in certain aspect especially the use of language style and the freedom of expression which is implemented through character, , and extrinsic aspects wich be mission of the author's.

The literary works wich is part the science and technology contributes to the journey of the nation into a great nation. Therefore, the researchers suggested that the government give attention to the development of science and technology especially literature so that he can synergize in building the character of Indonesian human resources. The issues investigated in this study are only a small part of the historical of development of Indonesian literature. Therefore, researchers suggest to literary researchers to explore the development of literature, especially metropop style or popular style so the works is not just a mere artifact. Researchers also suggested to writers and culturalists to always creating of works in order to participate in building the character of Indonesian human resources in the midst of the current modernization and globalization.

\section{References}

Ajidarma, Seno Gumira. (1996). Jazz, Parfum, dan Insiden. Yogyakarta: Bentang. Ayu, Djenar Maesa. (2005). Nayla. Jakarta: PT Gramedia Pustaka Utama.

Barry, Peter. (2002). Beginning Theory: An introduction to Literary and Cultural Theory (diunduh 17 Mei 2016).

Damono, Sapardi Djoko. (2016). Trilogi Soekram. Jakarta: PT Gramedia Pustaka Utama.

Dini, Nh. (1993). Tirai Menurun. Jakarta: PT Gramedia Pustaka Utama.

Foulcher dan Day. (2008). Sastra Indonesia Modern Kritik Postkolonial. Jakarta: Yayasan Obor Indonesia.

Navis, A.A. (2004). Gerhana. Jakarta: Buku Kompas.

Piaget, Jean. (1973). Structuralism. London: Routledge \& Kegan Paul.

Pradopo, Racmat Djoko.(2007). Beberapa Teori Sastra, Metode Kritik, dan Penerapannya. Yogyakarta: Pustaka Pelajar.

Rampan, Korrie Layun. (2000). Angkatan 2000. Jakarta: Penerbit Grasindo.

Stanton, Robert. (2007). Teori Fiksi. Yogyakarta: Pustaka Pelajar.

Sylado, Remy. (2016). Perempuan Bernama Arjuna 4. Jakarta: Bandung.

Toer, Pramudya Ananta. (1999). Arok Dedes. Jakarta: Lentera Dipantara.

Tohari, Ahmad. (2004). Orang-orang Proyek. Yogyakarta: Matahari.

Utami, Ayu. (1998). Saman. Jakarta: KPG.

Utami, Ayu. (2001). Larung. Jakarta: KPG. 